\title{
Inclusion of Yeast Cultures (Saccharomyces cerevisiae) to Dairy Cows' Urea-Treated Rice Straw Diets Improves Mozzarella Cheese Processing and Yield
}

\author{
Stephen Odera ${ }^{1 *}$, Olivier Basole Kashongwe ${ }^{2 *}$, Patrick Muliro Simiyu ${ }^{1}$, Bockline Omedo Bebe ${ }^{2}$ \\ ${ }^{1}$ Department of Dairy and Food Science and Technology, Egerton University, Egerton, Kenya \\ ${ }^{2}$ Department of Animal Sciences, Egerton University, Egerton, Kenya \\ Email: *stephenwill128@gmail.com
}

How to cite this paper: Odera, S., Kashongwe, O.B., Simiyu, P.M. and Bebe, B.O. (2020) Inclusion of Yeast Cultures (Saccharomyces cerevisiae) to Dairy Cows' Urea-Treated Rice Straw Diets Improves Mozzarella Cheese Processing and Yield. Food and Nutrition Sciences, 11, 11071116.

https://doi.org/10.4236/fns.2020.1112078

Received: September 16, 2020

Accepted: December 21, 2020

Published: December 24, 2020

Copyright $\odot 2020$ by author(s) and Scientific Research Publishing Inc. This work is licensed under the Creative Commons Attribution International License (CC BY 4.0).

http://creativecommons.org/licenses/by/4.0/

\begin{abstract}
This research paper addresses the hypothesis that adding yeast cultures (Saccharomyces cerevisiae) to urea-treated cereal crop residues could improve milk composition to the level of milk produced on pastures for the manufacture of Mozzarella cheese. In three equal groups, Nine Friesian cows were randomly assigned to three treatment diets in a completely randomized design. The treatments were pasture $(\mathrm{P})$, urea treated rice straw (UTRS), and urea treated rice straw with yeast inclusion (UTRS $+\mathrm{Y}$ ). Urea inclusion was at $3.8 \%$ of the dry matter to treat rice straw, while yeast culture inclusion was $10 \mathrm{~g} /$ cow/day. The experimental period was 21 days, with 14 days of adaptation. Data analysis used general linear model procedure of SAS, fitting diet as a fixed effect and milk composition, syneresis, curd firmness and cheese yield as the response variables. Milk produced on UTRS diet yielded $(\mathrm{p}<0.05)$ the highest fat content $(4.79 \%)$ and the lowest density $\left(1016.37 \mathrm{Kg} \cdot \mathrm{m}^{-3}\right)$ and casein-to-fat ratio (0.51). Yeast inclusion in the diet (UTRS + Y) significantly improved milk density $\left(1022.68 \mathrm{Kg} \cdot \mathrm{m}^{-3}\right)$ with marginal reduction in milk fat content (4.53\%). In cheese making, milk produced on URTS diets had significantly lower renneting time (1.4 minutes vs 3.47 minutes and 2.39 minutes), least viscous gel, lowest syneresis $(755 \mathrm{~mL}$ vs $860 \mathrm{~mL}$ and $836 \mathrm{~mL}$ from 1000 $\mathrm{mL}$ ), and lowest cheese yield (9.0\% vs $11 \%$ and $10.5 \%)$ compared to $\mathrm{P}$ and UTRS + Y diets. Milk produced from P and UTRS + Y did not show any significant difference in cheese yield. The findings indicated that urea treated rice straw with yeast cultures improves syneresis, gel viscosity and Mozzarella cheese yield. Therefore, we recommend the inclusion of yeast to urea treated cereal crop residues to produce milk destined for Mozzarella cheese making.
\end{abstract}




\section{Keywords}

Urea, Yeast, Crop Residues, Milk Composition, Cheese Yield

\section{Introduction}

Processability of milk into good quality cheese and cheese yield is very important to cheese makers. During the manufacture of Mozzarella cheese, low temperature pasteurised milk is subjected to renneting (addition of rennet enzyme) at $30^{\circ} \mathrm{C}$ and left to stand for at least 30 mins to form a white solid mass (curd). The curd is then cut and stirred to enhance contraction and whey expulsion (syneresis). Syneresis and curd firmness are essential determinants of cheese parameters, including cheese yield.

Milk composition, particularly protein and fat, among other factors, have been identified to impact on curd firmness, syneresis and cheese yield. High casein protein concentration, for instance, leads to greater curd firmness capacity associated with high cheese yield [1] [2]. An increase in milk fat is likely to lower the extent of syneresis, consequently increasing whey retention within the cheese protein matrix [3]. Impaired syneresis leads to the undesirable high moisture content in the final cheese associated with the product's reduced shelf life [4]. Besides, protein to fat ratio (PFR) of cheese milk has also been highlighted to significantly impact percentage recoveries of milk fat and, hence, cheese yield [5]. In cheese making, recovery of up to $93 \%$ of milk fat [6] is possible. However, this is only applicable to milk with casein-to-fat ratios of not lower than 0.64 [7]. These observations are suggestive that making good cheese is possible by manipulating the concentration of milk protein contents to balance milk fat contents.

Dependence on high fibre diets, especially crop residues for milk production among smallholder farms within Sub-Saharan Africa have dramatically increased [8]. Milk produced on the high fibre diets is of high fat and low protein contents, hence low PFR. Such milk is associated with impaired syneresis, weak curds and low cheese yield [9] [10]. However, treating crop residues with urea and yeast culture (Saccharomyces cerevisiae) are options for manipulating milk PFR needed to make good cheese.

Hence, this study seeks to explore the manipulation of high fibre cow diets with urea and yeast treatments to produce milk destined for making Mozzarella cheese. Urea inclusion in crop residue-based cow diets can improve protein levels of milk. Several studies have highlighted that the use of urea to treat crop residues such as rice straw improves milk protein contents in addition to improving feed intake and milk yield [11] [12] [13]. On the other hand, yeast culture inclusion in the cow diet provides vitamin B, amino acids, and organic acids. These are essential growth factors of major cellulolytic bacteria that, in turn, enhance protein synthesis [14]. 


\section{Materials and Methods}

\subsection{Formulation of the Improved Rice Straw}

Rice straws were shredded to $3-5 \mathrm{~cm}$ using a forage harvester (MC $90 \mathrm{~S}$ Twin, Kuhn, Germany). Urea treatment, as described by [15] of the straws at the rate of $3.8 \%$, then followed (Table 1 ).

\subsection{Milk Production}

The cow feeding experiment was done in October 2019, at the Tatton Agricultural Park of Egerton University. Milk was produced in a completely randomized design. Nine lactating Friesian cows were used in the experiment. This was so because at least three cows (replicates) were necessary for each treatment. They were then grouped into three groups at random [16]. Treatments; pasture (P), urea treated rice straw (UTRS), and urea treated rice straw with yeast (Saccharomyces cerevisiae) inclusion (UTRS + Y), were then offered randomly [16] to each group. Dairy meal was offered at the moment of milking in the morning and evening. Cows on pasture had ad libitum access to pasture while cows rice straw-based diets were fed in pens. Feeding of urea treated rice straw was at the rate of $10 \mathrm{Kg}$ per cow per day. During morning and evening milking, concentrates were offered at $6 \mathrm{Kg}$ per cow per day for all treatment groups. The inclusion of yeast was done by mixing a spoon full (10 g) of yeast [15] with the evening milking concentrate.

\subsection{Milk Composition Analysis}

Raw milk was chilled to $2^{\circ} \mathrm{C}$ and analysed for; fat, total protein, density, casein, and urea using near-infrared transmittance spectroscopy (Milko FT NIR scan) according to ISO 9622:2000 (ISO, 2000).

\subsection{Determination of Milk Renneting Time}

One litre of milk, from each treatment, was heated to $63^{\circ} \mathrm{C}$ in an aluminium pot and held for 30 minutes. After cooling to $30^{\circ} \mathrm{C}$, rennet was added. Renneting was done without any prior acidification. Time elapsed between the addition of the rennet to milk and the onset of visual coagulation [17] was then measured.

\subsection{Determination of Curd Viscosity, Syneresis and Cheese Yield}

We used an innovative technique, transient rotational viscometry, to compare the milk samples' gel properties. The samples were renneted based on the recommendations of [18]. After rennet addition, milk was immediately dispensed in beakers immersed in a $30^{\circ} \mathrm{C}$ water bath for 30 mins. Gel properties were after that determined using spindle number 64 of a rotational Brookfield DV-E Viscometer. Apparent viscosity was taken at two different speeds (10 revolutions per minute (rpm) and $20 \mathrm{rpm})$.

Viscosity readings of the samples at 20 seconds intervals for 6 minutes were as 
well recorded. Syneresis and cheese yield were determined according to procedures described by [17].

\subsection{Statistical Analysis}

Means values of response variables were determined and differences tested for significance at $\alpha=0.05$. SAS's general linear model procedure was used in the study, fitting diet as fixed effect and milk composition, clotting time, syneresis, curd firmness and cheese yield as the response variables.

\section{Results}

\subsection{Physical Chemical Composition of Milk}

Table 2 presents the Physico-chemical properties of milk produced on pasture, UTRS + Y and UTRS. Test diets (UTRS + Y and UTRS) had significant ( $\mathrm{p}<$ 0.05 ) effects on fat, casein to fat ratio and milk density. Pasture diets yielded lower milk fat than UTRS $(\mathrm{p}=0.017)$ and UTRS $+\mathrm{Y}(\mathrm{p}=0.047)$. Compared to the test diets, relatively higher milk density and casein to fat ratio were also recorded on pasture milk. Among the test diets, the UTRS diet yielded the lowest milk density $(p=0.018)$ and the lowest milk casein to fat ratios $(p=0.059)$. The analysis did not reveal any significant $(\mathrm{p}<0.05)$ difference in urea and FPD. However, compared to pasture milk, urea content was slightly high for UTRS + Y milk and even higher for UTRS produced milk. Results on SNF showed that the UTRS + Y diets resulted in high yields of all the SNF components (total proteins, caseins and lactose) relative to Pasture and UTRS diets; however, the differences were not $(\mathrm{p}<0.05)$ significant.

Table 1. Amount and chemical composition of diets.

\begin{tabular}{cccc}
\hline & \multicolumn{3}{c}{ Treatments } \\
\cline { 2 - 4 } & Pasture & UTRS + Y & UTRS \\
\hline Ingredients & Ad libitum & - & - \\
Grass & - & $10 \mathrm{Kg}$ & $10 \mathrm{Kg}$ \\
Rice straw & - & $0.38 \mathrm{Kg}$ & $0.38 \mathrm{Kg}$ \\
Urea & $6 \mathrm{Kg}$ & $6 \mathrm{Kg}$ & $6 \mathrm{Kg}$ \\
Dairy meal & - & $10 \mathrm{~g}$ & - \\
Yeast culture & & & \\
\hline Chemical composition & 18.2 & 95.79 & 14.8 \\
Dry Matter (\%) & 20.4 & 14.8 & 38.6 \\
Crude Protein (\%) & 32.7 & 38.6 & \\
Crude Fibre (\%) & & & \\
\hline
\end{tabular}


Table 2. Physicochemical properties of milk produced on pasture, rice straws treated with urea and rice straws treated with urea and yeast.

\begin{tabular}{cccccccc}
\hline Treatment & $\begin{array}{c}\text { Urea } \\
(\mathrm{mg} / \mathrm{dL})\end{array}$ & $\begin{array}{c}\text { Fat } \\
(\%)\end{array}$ & $\begin{array}{c}\text { Casein to } \\
\text { fat ratio }\end{array}$ & $\begin{array}{c}\text { Density } \\
\left(\mathrm{Kg} / \mathrm{m}^{3}\right)\end{array}$ & $\begin{array}{c}\text { Protein } \\
(\%)\end{array}$ & $\begin{array}{c}\text { Casein } \\
(\%)\end{array}$ & $\begin{array}{c}\text { Lactose } \\
(\%)\end{array}$ \\
\hline Pasture & $16.34^{\mathrm{a}}$ & $3.17^{\mathrm{b}}$ & $0.81^{\mathrm{a}}$ & $1024.07^{\mathrm{a}}$ & $3.19^{\mathrm{a}}$ & $2.38^{\mathrm{a}}$ & $4.67^{\mathrm{a}}$ \\
UTRS + Y & $17.77^{\mathrm{a}}$ & $4.53^{\mathrm{a}}$ & $0.59^{\mathrm{ab}}$ & $1022.68^{\mathrm{b}}$ & $3.57^{\mathrm{a}}$ & $2.62^{\mathrm{a}}$ & $4.70^{\mathrm{a}}$ \\
UTRS & $18.96^{\mathrm{a}}$ & $4.79^{\mathrm{a}}$ & $0.51^{\mathrm{b}}$ & $1016.37^{\mathrm{c}}$ & $3.45^{\mathrm{a}}$ & $2.45^{\mathrm{a}}$ & $4.35^{\mathrm{a}}$ \\
S.E. & 4.31 & 0.52 & 0.08 & 2.03 & 0.19 & 0.12 & 0.23 \\
\hline
\end{tabular}

Means in a column with different letter superscripts differ at $\mathrm{p}<0.05$. Diets: UTRS $+\mathrm{Y}=$ Urea treated rice straw with yeast; UTRS $=$ Urea treated rice straw without yeast; S.E. $=$ Standard error of the mean.

\subsection{Coagulation Time, Syneresis and Cheese Yield}

Results of milk clotting time, syneresis and cheese yield are presented in Table 3. Diets had significant $(\mathrm{p}<0.05)$ effects on coagulation time, syneresis and cheese yield, being constantly lowest with milk produced on UTRS diet and highest with milk produced on pasture. Milk from cows on (control diet) pasture had significantly $(\mathrm{p}<0.001)$ higher coagulation time compared to milk from UTRS and UTRS + Y diets. Syneresis was least observed from curds obtained from UTRS fed cows' milk which was significant $(\mathrm{p}=0.003)$ from the control. Pasture produced milk also resulted to highest yield of cheese though this did not significantly $(\mathrm{p}=0.319)$ differ from yield of cheese made using UTRS $+\mathrm{Y}$ derived milk.

\subsection{Curd Viscosity}

The curd viscosity profiles from the different diets are illustrated in Figure 1. Two regimes are shown: the first regime, Figure 1(a), shows the viscosity profiles of the gels at ten revolutions per minute $(10 \mathrm{rpm})$. The second one displays the viscosity profiles of the gels at $20 \mathrm{rpm}$. Milk produced on pasture diet (Line A) yielded the most significant apparent viscosity of 11,570 mPa.s and was characterised by the highest decrement in viscosity over time (highest sensitivity to torque) both at $10 \mathrm{rpm}$ (gradient of -18.46) and $20 \mathrm{rpm}$ (gradient of -6.6913). In comparison to milk produced on the UTRS diet at $10 \mathrm{rpm}$, curd from milk produced on the UTRS + Y diet had greater curd viscosity of 10,170 mPa.s vs. $6610 \mathrm{mPa} . \mathrm{s}$ ) and a higher sensitivity to torque over time (gradient of $-12.425 \mathrm{vs.}$ gradient of -10.171). The same trend was observed at $20 \mathrm{rpm}$.

\section{Discussion}

The high milk fat content obtained with UTRS diet can be related to high fibre content which stimulates acetate production, a primary precursor for milk fat synthesis in the rumen [19]. This observation concurs with the pioneer work of [20] and other recent observations [21] [22] that indicated positive association between high fibre diets with yield of milk fat content. In contrast, yeast inclusion in the high fibre diet depress acetate production as was observed with UTRS $+\mathrm{Y}$ diet, subsequently resulting in a drop in milk fat. However, yeast inclusion 
seemed to improve SNF contents including proteins as was consistently observed with UTRS + Y diet than UTRS diet. This suggests that yeast inclusion stimulate synthesis of milk solids synthesis by rumen bacteria on yeast inclusion [23].

Table 3. Coagulation time, syneresis and cheese yield of Mozzarella made from milk produced on the test diets.

\begin{tabular}{cccc}
\hline Treatment & CT (Minutes) & SYNERESIS (L) & YIELD (\%) \\
\hline Pasture & $3.47^{\mathrm{a}}$ & $860.00^{\mathrm{a}}$ & $11.0^{\mathrm{a}}$ \\
UTRS + Y & $2.39^{\mathrm{b}}$ & $835.50^{\mathrm{a}}$ & $10.5^{\mathrm{a}}$ \\
UTRS & $1.47^{\mathrm{c}}$ & $751.00^{\mathrm{b}}$ & $9.0^{\mathrm{b}}$ \\
S.E. & 0.03 & 9.56 & 0.28 \\
\hline
\end{tabular}

Means in a column with different letter superscript differ at $\mathrm{p}<0.05$. Diets: UTRS $+\mathrm{Y}=$ Urea treated rice straw with yeast; UTRS $=$ Urea treated rice straw without yeast. CT $=$ Coagulation time; S.E. $=$ Standard error of means.
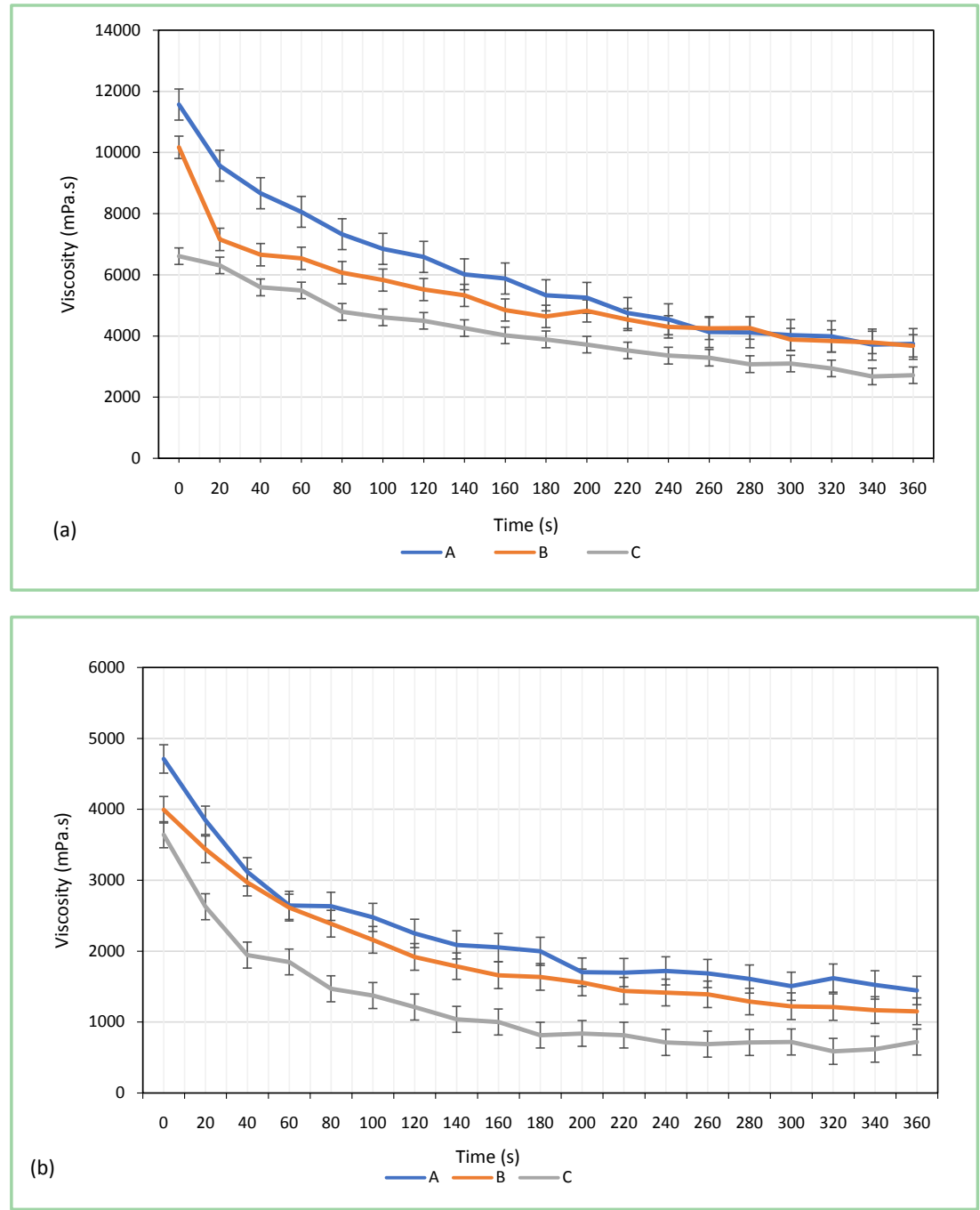

Figure 1. Graphs showing gel sensitivity to time at; (a) $10 \mathrm{rpm}$, (b) $20 \mathrm{rpm}$. Line A represents gel made from pasture milk; Line B represents gel made from URTS + Y milk; Line C represents gel made from URTS milk. 
The greater viscosity observed in pasture and UTRS $+\mathrm{Y}$ curds as compared to UTRS derived curd could be explained by findings from [24]. Their findings showed that high fat to protein ratios in milk leads to low curd firmness. An inverse association between curd viscosity and curd sensitivity to shear was also clearly notable. This is a striking observation in the study. To our knowledge, no information of this kind is reported in literature. We argued that milk with low fat contents resulted to more brittle (hard but more liable to breakage) curds and that increase in milk fat decreased curd brittleness. Although, the degree to which the brittleness could be attributed to fat contents was not clear from the study.

Extent of syneresis was lowest for treatment with the highest fat contents (UTRS) and highest for the treatment with the lowest fat content (pasture). The decrease in extent of syneresis as fat increases could possibly be due to the fact that fat globule membrane increases water holding capacity and decreases water mobility in the casein rennet gel [25]. This impairs whey expulsion.

Milk produced from cows fed UTRS had the least cheese yield. This was majorly linked to the losses observed during straining and curd plasticization [1]. It was notable that, due to formation of relatively weaker curds and hence insufficient entrapment of solids into the casein network [26], straining of UTRS derived curds was accompanied with much losses. Comparatively, more losses of liquid fats were also realized (though not quantified) in UTRS curds than pasture and UTRS + Y curds during stretching and working. From the standpoint, and as have been observed by previous studies [5], low protein to fat ratios in milk results to increased fat losses and hence low percentage milk fat recovery. Cheese yields for pasture derived milk and for UTRS + Y derived milk was on the other hand not significantly $(\mathrm{p}<0.05)$ different. This implied that cheese yield can be improved by urea and yeast treatments of the high roughage crop residue-based cow diets.

Wholly, these results point to the likelihood that yeast inclusion to urea-treated rice straw cow diet can improve the protein to fat ratio and casein to fat ratio of milk to the likeness of milk produced on pasture-based diets. A consequence of this is the possibility of increased curd viscosity, increased extent of syneresis and increased cheese yield, to a comparable level to milk produced on pastures. However, some of potential shortfalls need to be considered. First, straining water and whey were not analysed to determine the precise source of the losses. The small population size (9 cows) also made it impossible to draw decisive conclusions.

\section{Conclusion}

The study established that rice straw treatment with urea alone yielded milk with reduced syneresis and weak curds while adding yeast cultures to urea treatment cannot only improve syneresis and curd firmness but also improve cheese yield. Therefore, urea treatment with yeast culture for high fibre diet can be recom- 
mended as an alternative for pasture in producing milk destined for cheese making.

\section{Acknowledgements}

The authors wish to acknowledge RUFORUM through TAGDev Egerton University for providing research funds that made this research a success.

\section{Conflicts of Interest}

The authors declare no conflicts of interest regarding the publication of this paper.

\section{References}

[1] Aleandri, R., Schneider, J.C. and Buttazzoni, L.G. (1989) Evaluation of Milk for Cheese Production Based on Milk Characteristics and Formagraph Measures. Journal of Dairy Science, 72, 1967-1975. https://doi.org/10.3168/jds.S0022-0302(89)79319-X

[2] Pretto, D., De Marchi, M., Penasa, M. and Cassandro, M. (2013) Effect of Milk Composition and Coagulation Traits on Grana Padano Cheese Yield under Field Conditions. The Journal of Dairy Research, 80, 1-5. https://doi.org/10.1017/S0022029912000453

[3] Gilles, J. and Lawrence, R.C. (1985) The Yield of Cheese. New Zealand Journal of Dairy Science and Technology, 20, 205-214.

[4] Daviau, C., Famelart, M.H., Pierre, A., Goudédranche, H. and Maubois, J.L. (2000) Rennet Coagulation of Skim Milk and Curd Drainage: Effect of pH, Casein Concentration, Ionic Strength and Heat Treatment. Le Lait, 80, 397-415. https://doi.org/10.1051/lait:2000134

[5] Guinee, T.P., Mulholland, E.O., Kelly, J. and Callaghan, D.J.O. (2007) Effect of Protein-to-Fat Ratio of Milk on the Composition, Manufacturing Efficiency, and Yield of Cheddar Cheese. Journal of Dairy Science, 90, 110-123. https://doi.org/10.3168/jds.S0022-0302(07)72613-9

[6] Van Slyke, L.L. and Price, W.V. (1952) Cheese. Orange Judd Publ. Co., New York, 476.

[7] Yiadom-Farkye, N.A. (1984) Effect of Casein/Fat Ratio on Milk Fat Recovery in Cheddar Cheese.

[8] Valbuena, D., Tui, S.H.K., Erenstein, O., Teufel, N., Duncan, A., Abdoulaye, T. and Gérard, B. (2015) Identifying Determinants, Pressures and Trade-Offs of Crop Residue Use in Mixed Smallholder Farms in Sub-Saharan Africa and South Asia. Agricultural Systems, 134, 107-118. https://doi.org/10.1016/j.agsy.2014.05.013

[9] Wedholm, A., Hallén, E., Bach Larsen, L., Lindmark-Månsson, H., Hans Karlsson, A. and Allmere, T. (2006) Comparison of Milk Protein Composition in a Swedish and a Danish Dairy Herd Using Reversed Phase HPLC. Acta Agriculturae Scandinavica Section A, 56, 8-15. https://doi.org/10.1080/09064700600836745

[10] O’Callaghan, T.F., Mannion, D.T., Hennessy, D., McAuliffe, S., O’Sullivan, M.G., Leeuwendaal, N. and Stanton, C. (2017) Effect of Pasture versus Indoor Feeding Systems on Quality Characteristics, Nutritional Composition, and Sensory and Volatile Properties of Full-Fat Cheddar Cheese. Journal of Dairy Science, 100, 6053-6073. https://doi.org/10.3168/jds.2016-12508 
[11] Wanapat, M., Polyorach, S., Boonnop, K., Mapato, C. and Cherdthong, A. (2009) Effects of Treating Rice Straw with Urea or Urea and Calcium Hydroxide upon Intake, Digestibility, Rumen Fermentation and Milk Yield of Dairy Cows. Livestock Science, 125, 238-243. https://doi.org/10.1016/j.livsci.2009.05.001

[12] Mapato, C., Wanapat, M. and Cherdthong, A. (2010) Effects of Urea Treatment of Straw and Dietary Level of Vegetable Oil on Lactating Dairy Cows. Tropical Animal Health and Production, 42, 1635-1642. https://doi.org/10.1007/s11250-010-9613-3

[13] Hanafi, E.M., El Khadrawy, H.H., Ahmed, W.M. and Zaabal, M.M. (2012) Some Observations on Rice Straw with Emphasis on Updates of Its Management. World Applied Sciences Journal, 16, 354-361.

[14] Tripathi, M.K. and Karim, S.A. (2010) Effect of Individual and Mixed Live Yeast Culture Feeding on Growth Performance, Nutrient Utilization and Microbial Crude Protein Synthesis in Lambs. Animal Feed Science and Technology, 155, 163-171. https://doi.org/10.1016/j.anifeedsci.2009.11.007

[15] Kashongwe, O.B., Migwi, P., Bebe, B.O., Ooro, P.A., Onyango, T.A. and Osoo, J.O. (2014) Improving the Nutritive Value of Wheat Straw with Urea and Yeast Culture for Dry Season Feeding of Dairy Cows. Tropical Animal Health and Production, 46, 1009-1014. https://doi.org/10.1007/s11250-014-0598-1

[16] Gupta, S. and Shabbir, J. (2008) On Improvement in Estimating the Population Mean in Simple Random Sampling. Journal of Applied Statistics, 35, 559-566. https://doi.org/10.1080/02664760701835839

[17] Fox, P.F., Cogan, T.M. and Guinee, T.P. (2017) Factors That Affect the Quality of Cheese. In: Cheese, Academic Press, Cambridge, 617-641.

https://doi.org/10.1016/B978-0-12-417012-4.00025-9

[18] Cecchinato, A., Cipolat-Gotet, C., Casellas, J., Penasa, M., Rossoni, A. and Bittante, G. (2013) Genetic Analysis of Rennet Coagulation time, Curd-Firming Rate, and Curd Firmness Assessed over an Extended Testing Period Using Mechanical and NearInfrared Instruments. Journal of Dairy Science, 96, 50-62. https://doi.org/10.3168/jds.2012-5784

[19] Miller-Webster, T., Hoover, W.H., Holt, M. and Nocek, J.E. (2002) Influence of Yeast Culture on Ruminal Microbial Metabolism in Continuous Culture. Journal of Dairy Science, 85, 2009-2014. https://doi.org/10.3168/jds.S0022-0302(02)74277-X

[20] Tyznik, W.J. (1951) The Effect of the Amount and Physical State of the Roughage upon the Rumen Fatty Acids and Milk Fat of Dairy Cows. University of Wisconsin, Madison.

[21] Hart, K.J., Huntington, J.A., Wilkinson, R.G., Bartram, C.G. and Sinclair, L.A. (2015) The Influence of Grass Silage-to-Maize Silage Ratio and Concentrate Composition on Methane Emissions, Performance and Milk Composition of Dairy Cows. Animal, 9, 983-991. https://doi.org/10.1017/S1751731115000208

[22] Urrutia, N., Bomberger, R., Matamoros, C. and Harvatine, K.J. (2019) Effect of Dietary Supplementation of Sodium Acetate and Calcium Butyrate on Milk Fat Synthesis in Lactating Dairy Cows. Journal of Dairy Science, 102, 5172-5181. https://doi.org/10.3168/jds.2018-16024

[23] Mao, H.L., Wang, J.K., Liu, J.X. and Yoon, I. (2013) Effects of Saccharomyces cerevisiae Fermentation Product on in Vitro Fermentation and Microbial Communities of Low-Quality Forages and Mixed Diets. Journal of Animal Science, 91, 3291-3298. https://doi.org/10.2527/jas.2012-5851

[24] Mateo, M.J., Everard, C.D., Fagan, C.C., O’Donnell, C.P., Castillo, M., Payne, F.A. and O'Callaghan, D.J. (2009) Effect of Milk Fat Concentration and Gel Firmness on 
Syneresis during Curd Stirring in Cheese-Making. International Dairy Journal, 19, 264-268. https://doi.org/10.1016/j.idairyj.2008.10.014

[25] Métais, A., Cambert, M., Riaublanc, A. and Mariette, F. (2006) Influence of Fat Globule Membrane Composition on Water Holding Capacity and Water Mobility in Casein Rennet Gel: A Nuclear Magnetic Resonance Self-Diffusion and Relaxation Study. International Dairy Journal, 16, 344-353.

https://doi.org/10.1016/j.idairyj.2005.03.011

[26] Bobbo, T., Cipolat-Gotet, C., Bittante, G. and Cecchinato, A. (2016) The Nonlinear Effect of Somatic Cell Count on Milk Composition, Coagulation Properties, Curd Firmness Modeling, Cheese Yield, and Curd Nutrient Recovery. Journal of Dairy Science, 99, 5104-5119. https://doi.org/10.3168/jds.2015-10512 